\title{
Social Capital, Relational Goods, and Terms and Level of Exchange
}

\author{
Lindon J. Robison'1, Trey Malone¹, Jeffrey O. Oliver², Valentia Bali³, Richard E. Winder ${ }^{4}$ \\ ${ }^{1}$ Department of Agricultural Economics, Michigan State University, East Lansing, Michigan, USA \\ ${ }^{2}$ Department of Sociology and Social Work, Brigham Young University Idaho, Rexburg, Idaho, USA \\ ${ }^{3}$ Department of Political Science, Michigan State University, East Lansing, Michigan, USA \\ ${ }^{4}$ Leadership Dynamics Research Institute, Haslett, Michigan, USA \\ Email: robison@msu.edu
}

How to cite this paper: Robison, L. J., Malone, T., Oliver, J. O., Bali, V., \& Winder, R. E. (2020). Social Capital, Relational Goods, and Terms and Level of Exchange. Modern Economy, 11, 1288-1306. https://doi.org/10.4236/me.2020.117092

Received: June 10, 2020

Accepted: July 13, 2020

Published: July 16, 2020

Copyright (c) 2020 by author(s) and Scientific Research Publishing Inc. This work is licensed under the Creative Commons Attribution International License (CC BY 4.0).

http://creativecommons.org/licenses/by/4.0/

(cc) (i) Open Access

\begin{abstract}
A growing body of literature emphasizes the influence of social relationships of sympathy/empathy, trust, and regard-social capital, on the terms and level of economic transactions. This paper aims to clarify the relationship between social motivations and economic decision-making. Using primary data on the motives for 4180 economic transactions, this study supports the notion that economic transactions often depend on social relationship related motives, which are often neglected in traditional economic analysis. Relative to commodity transactions such as the purchase of gasoline motivated mostly by own-consumption considerations, relational goods transactions such as getting a haircut, voting, and recycling depend more on social capital related motives. The evidence from this study suggests that neoclassical economic models fit well when describing exchanges of commodities in a monetary market transaction but might be misleading when applied to economic transactions where selfish motives play a less significant role in the exchange. Furthermore, our evidence provides additional support to the notion that motives vary across exchange activities in a manner consistent with the nature of the transaction.
\end{abstract}

\section{Keywords}

Social Capital, Relational Goods, Social Motivations, Terms and Level of Exchange

\section{Introduction}

Early thinkers such as Adam Smith, David Hume, and Antonio Genovesi recognized the importance of trusting relationships on the terms and level at which 
good and services were exchanged (Bruni \& Sugden, 2000). Polanyi (1944) taught that in some societies, exchanges of goods and services were embedded in personal relationships and religious and political institutions. Granovetter (1985) observed that even in the most rational economic exchanges, the terms and level of exchange were influenced by pre-existing social ties. Meanwhile, Uzzi (1997) acknowledged the role of social structure on economic transactions but questioned whether their influence facilitated or impeded economic action. Supporting the claim that social relationships alter the terms and level of exchange, Siles et al. (2000) and Perry and Robison (2001) found that the minimum sell price for farmland depended on whether the seller viewed the potential buyer as an unfriendly neighbor, a stranger, a friend, or a family member.

For much of the twentieth century, mainstream neoclassical economic theory chose to ignore the importance of relationships in favor of selfish preferences expressed in precise mathematical models (Hoff \& Stiglitz, 2016). As Etzioni (1991: p. 3) noted, "The neoclassical paradigm, we have seen, attempts to show not merely that there is an element of pleasure in all seemingly altruistic behavior, but that self-interest can explain it all".

In the 1970s, economic theory increased its focus on nonmarket outcomes. Manski (2000) wrote that the adoption of noncooperative game theory, among other things, allowed economists to break down the often-sharp distinction between market and social interactions. Since then, behavioral economists have become increasingly bold in pointing out the failures of traditional economic theory to explain predictably irrational choices (Ariely, 2008).

What we have now is a general acceptance that under some important conditions, relationships alter the terms and level of commodity exchanges. What we don't have is a generally accepted description of how relationships alter the terms and level of commodity exchanges. This paper proposes that: 1) social capital rich relationship produces relational goods; 2) relational goods can be included in commodity exchanges; and 3) the relative importance of relational goods exchanged determines the level and terms of commodity exchanges.

To test this paper's explanation about how relationships alter the terms and level of commodity exchanges, we present an expanded view of needs. Besides the physical need for commodities, we are reminded of socio-emotional needs for internal and external validation, belongings, and caring (Maslow, 1943). In addition to accounting for socio emotional as well as commodity needs, this paper reviews an expanded set of exchange motives including the neoclassical economic model's "selfishness" or own consumption motive and four social capital motives including motives to satisfy the needs for internal and external validation, belonging, and caring (Robison et al., 2012). Then this paper tests the hypothesis that as the relative importance of relational good included in an exchange increase, so does the relative importance of social capital motives.

In what follows, we describe the theoretical framework for this paper by establishing the connection between social capital rich networks and the creation of 
relational goods. Then we compare relational goods and commodities and the needs and motives that encourage their exchange. Next, we describe the survey we used to gather data for testing this paper's hypothesis-that as the relative importance of relational goods exchanged increases, so does the relative importance of social capital motives. Following, we report our findings. This article concludes with a discussion of the implications and limitations of our study and suggestions for future research.

\section{Theoretical Framework}

Many articles have explored how personal relationships can change the value and meaning of goods creating a new class of goods referred to as relational goods. The value of "relational goods" has been discussed in some detail by Uhlaner (1989), Gui and Sugden (2005), Becchetti. Pelloni, and Rossetti (2008), and Bruni and Stanca (2008). These authors share the view that the value of relational goods depends in part on their connection to the people who produce, exchange, consume, and preserve them. Relational goods have been shown to improve well-being (Rasciute, Downward, \& Greene, 2017). Indeed, research suggests that an increase in time spent on social relationships is likely to increase self-reported happiness (Becchetti, Trovato, \& Bedoya, 2011). Finally, accounting for relational goods in transactions may explain what sometimes has been referred to as economic misbehaving (Robison \& Oliver, 2019).

Robison and Ritchie (2010) explained how relationships can create new goods and change the nature of other goods. They proposed that one's social capital defined as relationships of sympathy/empathy, regard and trust (Robison, Schmid, \& Siles, 2002), can produce intangible socio-emotional goods that satisfy basic socio emotional needs. Furthermore, they proposed that when socio-emotional goods become embedded in things, the meaning and value of the embedded things change, creating attachment-value goods (Robison \& Flora, 2003; Frey, 2007). Both socio-emotional goods and attachment-value goods satisfy the description of relational goods because social-capital-rich relationships produce them and because they satisfy socio-emotional needs.

The direct exchange of socio-emotional goods between persons depends on the nature of their relationship, that is, the social capital that exists between them. For example, socio-emotional goods may be produced and exchanged when two friends greet each other, recognize admirable qualities in each other, and make mention of each other's achievements. Additionally, socio-emotional goods are produced and exchanged when one person makes a commitment to another or includes the other person in a significant event.

Alternatively, exchanges of attachment-value goods depend on the connection between the good exchanged and the social capital source of the embedded socio-emotional goods. For example, an attachment-value good may be created when a famous person signs an autograph or endorses a product, when one offers or accepts an engagement ring, or when one receives an honorific good sig- 
naling unusual achievement at work, in sports, or in other settings. When attachment-value goods are exchanged, social capital between exchange partners is not required.

Because people exchange relational goods and commodities separately and together, it is important that we carefully distinguish between them.

1) Conditions of exchange. We exchange commodities in mostly impersonal settings. Furthermore, commodity buyers are not generally connected socially to those who produce and market the product. As a result, commodities have not acquired attachment-value. Commodity exchange examples include exchanges with a vending machine, on-line purchases, buying gasoline at a self-serve gasoline station, and exchanges with ATM machines. We exchange relational goods in personalized settings in which either buyers and/or sellers are known to each other or the good exchanged is associated with a social-capital-rich person. Examples of personalized exchanges include engaging a service person in a restaurant, dinner with friends, being part of a fan group at a sporting event, promoting a cause with other likeminded persons, and family events that celebrate births, deaths, marriages, and other achievements.

2) Terms and levels of exchange. The terms and levels at which commodities are exchanged are determined by the aggregate of market participants and apply generally to similar commodities. The terms and levels at which relational goods are exchanged depend on the relationships between those who consume, produce, market, and preserve them. To illustrate, everyone who purchases gasoline at the same self-service station in the same time period pays the same price. The same is true for products purchased in most supermarkets. However, the price at which one sells a used car to a friend may be much different from the price one offers the same car to a stranger even during the same time-period (Robison \& Schmid, 1991).

3) Substitutability. Commodities are standardized goods of uniform quality that make them near perfect substitutes for each other. However, commodities are typically poor substitutes for relational goods because they satisfy different needs. Flowers from an admirer do not substitute for the identical flowers awarded as a door prize. A ring from a friend and a ring purchased for oneself at a jeweler satisfy different needs. In contrast, gasoline purchased at one gasoline station is a near-perfect substitute for gasoline purchased at a different gasoline station.

4) Valuation. We infer the value of commodities from their (mostly) observable physical properties and the importance of the physical needs they satisfy. The value of relational goods depends in part on unobservable socio-emotional goods produced in social-capital-rich relationships and the socio-emotional needs they satisfy. A baseball purchased at a sporting goods store is valued differently from the physically identical baseball hit for a home run by a famous player in an important sporting event. The value of an item of clothing may increase if it signals inclusion. 
5) Capital used in production. Manufactured, natural, human, and financial capital may all play important roles in the production of commodities. The production of relational goods requires social capital.

6) Value added. We may change the value of commodities by changing their form, function, location, and other physical properties. We may alter the value of relational goods by changing their connections to people who produce, exchange, consume, or preserve them. Indeed, much of advertising involves famous people signaling their approval and connection to a product.

7) Needs. Commodities satisfy mostly physical needs and wants. Relational goods satisfy mostly socio-emotional needs and wants including internal and external validation, belonging, and caring.

8) Durability. Commodities are mostly nondurable goods with a short useful life. As a result, they are not likely to become embedded with socio-emotional goods produced in social-capital-rich networks. The exception to this description might be when a nondurable good represents a durable brand or a repeatedly consumed good. For example, a special dessert may be a nondurable good but if it is repeatedly served at special events where persons in a social-capital-rich network gather, it may be viewed as a relational good.

Relational goods embedded with socio-emotional goods (i.e., attachment-value goods) are mostly durable things with a useful life sufficiently long to become embedded with socio-emotional goods generated in social-capital-rich networks.

9) Certification. Commodities are most likely to have their quantity and quality certified by arm's length agencies established for that purpose. Relational goods are most likely to have their quantity and quality assured by the social capital inherent in relationships.

\section{Motives}

The five motives developed in Robison et al.'s (2012) social capital model depended on both physical and socio-emotional needs. The motive most consistent with neoclassical utility theory is the "own consumption" motive, the desire to increase one's own commodity consumption. Taken to its extreme, this notion can lead to a belief in the "virtue of selfishness" (Rand, 1964). This explanation for economic exchanges appears to be inconsistent with recent research that suggests that increasing income does not always lead to more subjective well-being (Becchetti, Pelloni, \& Rossetti, 2008; Kahneman \& Deaton, 2010).

The other four motives in the Robison et al. (2012) social capital model derive from socio-emotional needs or wants. We earlier referred to these motives collectively as social capital motives. The first social capital motive is to satisfy one's need for internal validation. This motive encourages us to act in harmony with our ideal self or what Frank (2008) defined as our moral emotions. This motive is referred to as the "self-respect" motive and is related to self-control (Battaglini, Dias, \& Patacchini, 2017; Kocher et al., 2017). Our ideal self has been described as our "own social capital," and choices consistent with our ideal self are viewed as investments in our own social capital. This motive may explain why 
we return lost wallets, do not take advantage of others even when we have opportunities to do so, make anonymous contributions, and keep the rules and our promises even when they cannot be enforced.

Our second social capital motive is to satisfy our need for external validation by acting in ways that win the "good-will" and approval of important others. We call this motive the "good-will" motive. The good will of others can be viewed as the social capital from which we receive external validation. This motive may explain why we sometimes "dress for success," attempt to impress the boss, buy presents on special occasions for people whose good will we value, perform services when asked, and praise the success of others.

Our third social capital motive is to satisfy our need to belong which is firmly rooted in the tribal nature of human evolution (Greene, 2014; Haidt, 2012). We call the motive to belong, the "belonging" motive which causes us to increase our feelings of empathy toward other people, causes, and organizations, especially when we lack the ability or resources to change the empathetic feelings and attitudes others have toward us. In other words, the belonging motive calls for us to increase the social capital we have for others. This motive may explain why we join clubs, volunteer, wear school colors at home games, or contribute to public radio stations.

Finally, our social capital (empathetic) connections to others internalize their well-being, motivating us to act in their interest often by sharing our resources with them. This fourth social capital motive, referred to here as the "sharing" motive, may be rooted in the value of reciprocity (Becker \& Clement, 2006). The sharing motive may explain why some soldiers risk their lives to rescue their comrades and why people donate blood, raise children, volunteer at relief centers, and donate to charities. Additionally, the sharing motive might also be considered a "fairness" or "justice" motive, which has been found to motivate anomalous behavior in economics experiments (Lopes, 2008). It also might explain why people become unhealthy when the health status of their loved one deteriorates (de Mello \& Tiongson, 2009). The sharing motive can also be referred to as the altruism motive that leads persons to act in the interest of others.

\section{Exchanges of Commodities and Relational Goods}

We wanted to test the hypothesis that the relative importance of social capital motives varies with the relative importance of relational goods exchanged. To do so, we needed to identify exchanges that included varying combinations of relational goods and commodities. Guided by the characteristics that corresponded to commodities versus relational goods already described, we selected four activities. The four exchange activities we selected were buying gasoline, buying a haircut, recycling, and voting. We describe the commodity and relational good characteristics of these exchanges in Table 1.

Gasoline is mostly a commodity. It is exchanged mostly for money. With the transition to self-service pumps, the exchange of money for gasoline itself requires very little social interaction (Basker, Foster, \& Klimek, 2017). Because of 
Table 1. Commodity and relational good characteristics associated with the purchasing of gasoline, purchasing a haircut, recycling, and voting.

\begin{tabular}{|c|c|c|c|c|}
\hline Properties & Purchasing gasoline & Purchasing a haircut & Recycling & Voting \\
\hline Exchange setting & $\begin{array}{l}\text { Impersonal market } \\
\text { setting. }\end{array}$ & $\begin{array}{l}\text { Market setting with personalized } \\
\text { service. }\end{array}$ & $\begin{array}{l}\text { Nonmarket personalized or } \\
\text { non-personalized setting } \\
\text { depending on where recycling } \\
\text { occurs. }\end{array}$ & Personalized non-market setting. \\
\hline $\begin{array}{l}\text { How terms and level } \\
\text { of exchange are } \\
\text { determined }\end{array}$ & Market determined. & $\begin{array}{l}\text { Amount of tip is personally } \\
\text { determined and depends on the } \\
\text { customer/barber relationship. }\end{array}$ & $\begin{array}{l}\text { Time, effort, and commodities } \\
\text { spent recycling are personally } \\
\text { determined. }\end{array}$ & $\begin{array}{l}\text { Time, effort, and commodities } \\
\text { spent voting are personally } \\
\text { determined. }\end{array}$ \\
\hline Substitutability & $\begin{array}{l}\text { Near perfect } \\
\text { substitutes exist. }\end{array}$ & $\begin{array}{l}\text { One barber/stylist is not a perfect } \\
\text { substitute for another. Depends } \\
\text { on customer preference. }\end{array}$ & $\begin{array}{l}\text { Few substitutes exist for } \\
\text { recycling. }\end{array}$ & No good substitutes for voting. \\
\hline $\begin{array}{l}\text { What determines the } \\
\text { value of the good }\end{array}$ & $\begin{array}{l}\text { Depends mostly on } \\
\text { physical properties. }\end{array}$ & $\begin{array}{l}\text { Depends on physical properties } \\
\text { and the relational goods } \\
\text { exchanged during the service. }\end{array}$ & $\begin{array}{l}\text { Depends mostly on the } \\
\text { relational goods received when } \\
\text { recycling. }\end{array}$ & $\begin{array}{l}\text { Depends mostly on the relational } \\
\text { goods received when voting. }\end{array}$ \\
\hline $\begin{array}{l}\text { Capital used in the } \\
\text { productions of the } \\
\text { good. }\end{array}$ & $\begin{array}{l}\text { Mostly manufactured, } \\
\text { natural, human, and } \\
\text { financial capital. }\end{array}$ & $\begin{array}{l}\text { Combination of manufactured, } \\
\text { natural, human, financial capital } \\
\text { and social capital }\end{array}$ & $\begin{array}{l}\text { Combination of manufactured, } \\
\text { natural, human, financial } \\
\text { capital and social capital }\end{array}$ & $\begin{array}{l}\text { Combination of manufactured, } \\
\text { natural, human, financial capital } \\
\text { but mainly social capital }\end{array}$ \\
\hline $\begin{array}{l}\text { How the value of the } \\
\text { good is changed }\end{array}$ & $\begin{array}{l}\text { Impersonal market } \\
\text { forces. }\end{array}$ & $\begin{array}{l}\text { Depends on exchanges of relational } \\
\text { goods during the haircut and the } \\
\text { quality of the haircut. }\end{array}$ & $\begin{array}{l}\text { Depends on exchanges of } \\
\text { relational goods associated with } \\
\text { recycling. }\end{array}$ & $\begin{array}{l}\text { Depends on exchanges of } \\
\text { relational goods associated with } \\
\text { voting. }\end{array}$ \\
\hline Needs satisfied & $\begin{array}{l}\text { Mostly physical } \\
\text { transportation needs. }\end{array}$ & $\begin{array}{l}\text { Mostly socio-emotional needs for } \\
\text { internal and external validation, } \\
\text { some belonging needs, and some } \\
\text { physical needs associated with } \\
\text { hair length management. }\end{array}$ & $\begin{array}{l}\text { Mostly socio emotional needs } \\
\text { for internal validation-that } \\
\text { one is doing the right thing. }\end{array}$ & $\begin{array}{l}\text { Mostly socio emotional needs for } \\
\text { internal validation-that one is } \\
\text { doing the right thing and external } \\
\text { validation from approving others. }\end{array}$ \\
\hline Durability & Not durable. & $\begin{array}{l}\text { Limited durability but frequently } \\
\text { repeated. }\end{array}$ & $\begin{array}{l}\text { Mostly non-durable but } \\
\text { frequently repeated. }\end{array}$ & $\begin{array}{l}\text { Mostly non-durable but } \\
\text { frequently repeated. }\end{array}$ \\
\hline Certification & Externally regulated. & $\begin{array}{l}\text { Some external regulation through } \\
\text { inspections but customer is most } \\
\text { often the one certifying the } \\
\text { quality of the service. }\end{array}$ & $\begin{array}{l}\text { Some external certification on } \\
\text { what materials can be recycled } \\
\text { but recyclers internally certify } \\
\text { most of the recycling. }\end{array}$ & $\begin{array}{l}\text { Some external certification on } \\
\text { how to vote but most of the } \\
\text { voting certification is internally } \\
\text { provided. }\end{array}$ \\
\hline
\end{tabular}

gasoline's "commodity-like" properties, we hypothesize that most consumers consider gasoline sold at different stations to be nearly perfect substitutes and hypothesize that the own consumption motive can explain most gasoline purchases.

In contrast to purchasing gasoline, purchasing haircuts is a personalized service-based transaction, making it likely that traditional neoclassical predictions about price changes might not hold (Kosonen, 2015). Furthermore, because there is extended contact between the person providing and the person receiving the service, there will likely be exchanges of relational goods in which social capital can develop-like the development of social ties between lawyers and their clients (Kim, 2009). The relationship between the barber/stylist and customer will determine the significance of relational goods included in the exchange. In most haircutting establishments, the terms and level of trade are standard but 
allow for tipping that personalizes the terms of exchange. In addition, some barbers/stylists, depending on the social capital that exists between them and their customers, provide special services not afforded casual customers. We hypothesize that the most important motives for buying a haircut are a mix of social capital and own consumption motives.

We expect that social capital motives can explain mostly relational good exchanges. We studied two such exchanges. The first one was recycling. Recycling requires an exchange of commodities (resources expended to recycle) but recyclers are not generally paid with commodities or money for their efforts (Joshi et al., 2015). What recyclers do receive from recycling are relational goods that depend on the social capital of those approving of and supporting the recycling efforts, including one's ideal self. For example, one may recycle anonymously by dropping off recyclables in public recycling stations at night, which would not create social capital. Alternatively, one may recycle in social setting, observed by others and thereby increasing the recycler's social capital and external validation. We hypothesize that we are motivated to recycle by the need for internal validation from our ideal self, the self-respect motive (doing the right thing); by the need for external validation, the good will motive (people will approve of my taking the time to recycle) and the need to belong, the belonging motive (recycling helps me feel included by my participating in an important public process). Supporting our motives hypothesis for recycling is research suggesting that prosocial behavior in general, can be encouraged by external validation and recognition (Barile, Cullis, and Jones, 2015).

The second mostly relational good exchange we studied was voting. Voting does not require a market exchange nor is there a commodity exchange. While voters may consider their own self-interest when they cast their ballot, voters also consider the social-or "expressive"-implications of their choice (Abrams, Iversen, \& Soskice, 2010; Brennan \& Lomasky, 1997; Caplan, 2011). Even the decision to vote is likely influenced by personal relationships formed by the voters (Feddersen \& Sandroni, 2006), and social images may be a crucial component of the decision to vote (DellaVigna et al., 2016).

At times, the relational nature of voting might make electoral choices appear irrational, such as occurred in 2008, when $63.5 \%$ of Californian voters chose to ban the sale of eggs from traditional chicken cages even though more than $90 \%$ of the eggs purchased in California came from these systems (Malone \& Lusk, 2016). We hypothesize that we are motivated to vote by the need for internal validation from our ideal self, the self-respect motive (doing the right thing); by the need for external validation, the good will motive (people will approve of my taking the time to vote) and the need to belong, the belonging motive (voting helps me feel included by my participating in an important public process).

To help the respondents make informed allocations, we provided specific instances of the five motives when participating in the 4 exchange activities. We summarize the correspondence between motives and the four exchanges in $\mathrm{Ta}$ ble 2. 
Table 2. Motives/Reasons provided to respondents.

\begin{tabular}{|c|c|c|c|c|}
\hline & Purchasing Gasoline & Purchasing a Haircut & Recycling & Voting \\
\hline $\begin{array}{c}\text { Own } \\
\text { Consumption }\end{array}$ & $\begin{array}{l}\text { To save money or time (for } \\
\text { example, if you try to find the } \\
\text { lowest price, if you shop at the } \\
\text { most convenient location, or if } \\
\text { you gain rewards points.) }\end{array}$ & $\begin{array}{l}\text { I get a haircut at a place where I will } \\
\text { save money or time. For example. I } \\
\text { try to find the lowest price, the most } \\
\text { convenient location, or the best } \\
\text { value. }\end{array}$ & $\begin{array}{l}\text { To make money or reduce } \\
\text { expenses (for example, you } \\
\text { recycle aluminum cans to } \\
\text { earn money or to reduce } \\
\text { waste disposal costs). }\end{array}$ & $\begin{array}{l}\text { I vote to increase my income or } \\
\text { reduce my expenses (for example, } \\
\text { I vote because there is a potential } \\
\text { economic benefit, such as } \\
\text { reducing taxes or increasing } \\
\text { government benefits). }\end{array}$ \\
\hline Goodwill & $\begin{array}{l}\text { I purchase gasoline where I } \\
\text { want my friends and colleagues } \\
\text { to see and notice me. }\end{array}$ & $\begin{array}{l}\text { I get my haircut at a place where I } \\
\text { want my friends or co-workers to see } \\
\text { me since it improves my image or } \\
\text { standing among them. }\end{array}$ & $\begin{array}{l}\text { I recycle because of peer } \\
\text { expectations or so that my } \\
\text { friends and co-workers will } \\
\text { think more highly of me. }\end{array}$ & $\begin{array}{l}\text { I vote so that my friends and } \\
\text { co-workers will think better of } \\
\text { me. }\end{array}$ \\
\hline Self-respect & $\begin{array}{l}\text { To increase my self-respect by } \\
\text { purchasing from socially or } \\
\text { environmentally responsible } \\
\text { companies. }\end{array}$ & $\begin{array}{l}\text { I get my haircut at a given place } \\
\text { because I feel I should; it makes me } \\
\text { feel good about myself (for example, } \\
\text { because of the quality of the haircut } \\
\text { or the way I'm treated by the barber } \\
\text { or hairdresser). }\end{array}$ & $\begin{array}{l}\text { I recycle because I think it } \\
\text { is the right thing to do and } \\
\text { I feel better about myself } \\
\text { when I do. }\end{array}$ & $\begin{array}{l}\text { I vote because I think it is the } \\
\text { right thing to do and I feel } \\
\text { better about myself when I do. }\end{array}$ \\
\hline Belonging & $\begin{array}{l}\text { I purchase gasoline where I am } \\
\text { more likely to run into and talk } \\
\text { to my friends and colleagues. }\end{array}$ & $\begin{array}{l}\text { I get my haircut at a place where I } \\
\text { am more likely to encounter my } \\
\text { friends and co-workers or where I } \\
\text { will feel part of a larger community. }\end{array}$ & $\begin{array}{l}\text { I recycle because it makes } \\
\text { me feel like a part of a } \\
\text { larger recycling community } \\
\text { or effort. }\end{array}$ & $\begin{array}{l}\text { I vote because it makes me feel } \\
\text { like I am participating in } \\
\text { something larger than myself it } \\
\text { makes me feel like I am part of a } \\
\text { community. }\end{array}$ \\
\hline Sharing & $\begin{array}{l}\text { To support the workers and } \\
\text { owners associated with the gas } \\
\text { station or gas company. }\end{array}$ & $\begin{array}{l}\text { I get my haircut at a given place to } \\
\text { support the barber or hairdresser, or } \\
\text { the company for which they work. }\end{array}$ & $\begin{array}{l}\text { I recycle because I want to } \\
\text { leave the environment in } \\
\text { better shape for the people } \\
\text { I care about (e.g., friends, } \\
\text { children, grandchildren, } \\
\text { etc.). }\end{array}$ & $\begin{array}{l}\text { I vote to support people and } \\
\text { causes that I care about, so that } \\
\text { those people and causes may be } \\
\text { more successful. }\end{array}$ \\
\hline
\end{tabular}

\section{Respondent Demographics and Survey Design}

While prior studies have argued that accounting for social motives can improve our understanding of economic transactions, few experimental studies have been conducted to identify the relative importance of motives when exchanging relational goods and commodities (Biggart \& Castanias, 2001). To that end, we recruited one thousand forty-five respondents via Amazon Mechanical Turk (MTurk) from October 31, 2013, to November 15, 2013 to test whether the relative importance of social capital motives increase with the relative importance of relational goods included in an exchange.

The use of MTurk participants is well established in academic work (Dupuis, Endicott-Poposky, \& Crossler, 2013). Since its development, thousands of studies have been published using data collected via MTurk (Hitlin, 2016). Perhaps its popularity can be explained because it provides easy access to a large, stable, and diverse subject pool (Mason \& Suri, 2012). Prior research suggests that MTurk samples are often preferred to alternative sampling methods (Berinsky et al., 2012) in part because MTurk participants respond to surveys more attentively than alternative panels (Hauser \& Schwarz, 2016).

We describe respondents' demographic characteristics compared to the na- 
tional population in Table 3. The average respondent age was 35 compared to 37.8 in the U.S. population. Respondents' average reported income range was less than the median U.S. household income. The percentage of Caucasian respondents was higher, $80 \%$ compared to $61.3 \%$, in the U.S. population. As a result, our survey included lower percentages of African American and Hispanic respondents than the national average. Respondent's average education was higher than the national average; nearly $100 \%$ of respondents had at least a high school diploma, compared to $86.3 \%$ of the U.S. population. Finally, respondents' gender mix, compared to the U.S. population, was nearly equal.

Utilizing a within-subjects design, we used an online survey to ask respondents to reflect on the relative importance of their motives when buying gasoline, buying a haircut, recycling, and voting. We asked respondents to indicate the relative importance of the five motives. To do so, they allocated 100 points among the five motives in each of the four activities. The more points they allocated to a motive, the more important was the motive. We wanted to reduce any bias caused by the order in which the motives were presented. Therefore, we randomized the order in which they were presented. The survey questions are presented in Figure 1.

The method we described for measuring the relative importance of motives is preferable to traditional Likert-scale measures for two reasons. First, it avoids interpersonal comparison problems because participants all have the same number of points to allocate. Second, the total point constraint encourages participants to consider the tradeoffs associated with allocating points to alternative motives. Table 2 lists the reasons included in the survey why a person might select one of the five motives. In addition, the survey included an open response option where respondents could specify motives they thought were not included in Table 2. The last section of the survey asked for background information about the respondents such as gender, age, ethnic background, education level achieved, and household income.

Table 3. Survey respondent summary statistics and the U.S. Census population.

\begin{tabular}{ccc}
\hline Characteristics & Sample averages & U.S. population \\
\hline Age & 35.08 (average) & 37.8 (median) \\
Median household income & $\$ 40,000$ to $\$ 50,000$ & $\$ 55,775$ \\
White & $79.9 \%$ & $61.3 \%$ \\
African American & $6.3 \%$ & $13.3 \%$ \\
Asian & $4.7 \%$ & $5.6 \%$ \\
Hispanic & $5.7 \%$ & $17.6 \%$ \\
2 or more races & $0.6 \%$ & $2.6 \%$ \\
High School Education + & $99.7 \%$ & $86.3 \%$ \\
Gender (\% female) & $51.3 \%$ & $50.8 \%$ \\
\hline
\end{tabular}

Source for U.S. population: U.S. Census Bureau (2015). 


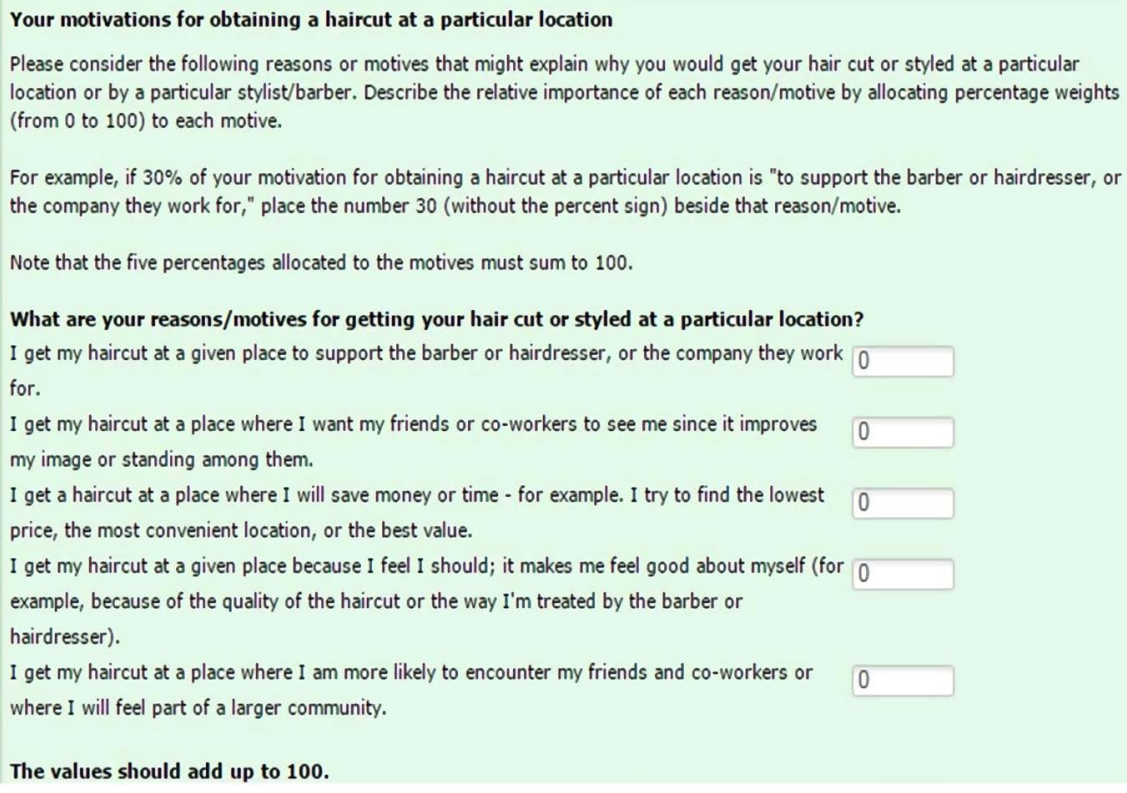

Figure 1. An example of the motives question.

\section{Survey Results}

We summarize our main survey results in Table 4 and Figure 2. Additional details are provided in the Appendix. Table 4 and Figure 2 report the means for the five motives across the four exchange activities: buying gasoline, buying a haircut, recycling, and voting. These results reveal that the relative importance of the own-consumption motive varies dramatically by activity. Gas purchases most nearly matched the characteristics of a commodity exchange and registered the only average own-consumption motive score greater than the sum of the average of the other social capital motives. Meanwhile, the haircut exchange motives are almost equally split between the own consumption and the four social capital motives. As expected, the importance of the own consumption motive decreased as the relative importance of relational goods included in the exchange increased.

The primary motive for purchasing gasoline was the own-consumption motive, which accounted for, on average, $86.2 \%$ of the decision. Getting a haircut was less motivated by the own-consumption motive ( $46.9 \%$ of the decision), but the own-consumption motive was substantially less important for voting (12.8\%) and recycling (16.4\%). Instead, the most important motives for voting and recycling were the sharing motive $(44.1 \%$ and $34.2 \%$, respectively) and the good-will motive $(22.6 \%$ and $33.4 \%$ respectively. As anticipated, social capital motives accounted for $87.2 \%$ of the decision to vote. Similarly, social capital motives accounted for $83.6 \%$ of the decision to recycle while $53.1 \%$ of the decision to buy a haircut was attributable to social motives.

The results in Table 4 and Figure 2 support this paper's hypothesis that as the relative importance of relational goods included in an exchange increase, so do the relative importance of social capital motives. These results provide an explanation 
Table 4. A comparison of the relative importance of motives.

\begin{tabular}{|c|c|c|c|c|}
\hline Motive & Mean & Standard Error & t-statistic & $p$-value \\
\hline \multicolumn{5}{|c|}{ Purchasing Gasoline } \\
\hline Own consumption & $87 \%$ & 2.43 & 35.8 & 0.000 \\
\hline Good will & $1 \%$ & 0.53 & 1.89 & 0.029 \\
\hline Self-respect & $4 \%$ & 1.05 & 3.81 & 0.000 \\
\hline Belonging & $2 \%$ & 0.95 & 2.11 & 0.017 \\
\hline Sharing & $6 \%$ & 1.48 & 4.05 & 0.000 \\
\hline \multicolumn{5}{|c|}{ Getting a Haircut } \\
\hline Own consumption & $47 \%$ & 4.21 & 11.16 & 0.000 \\
\hline Good will & $1 \%$ & 0.63 & 1.59 & 0.056 \\
\hline Self-respect & $29 \%$ & 3.48 & 8.33 & 0.000 \\
\hline Belonging & $2 \%$ & 0.84 & 2.41 & 0.008 \\
\hline Sharing & $21 \%$ & 3.16 & 6.65 & 0.000 \\
\hline \multicolumn{5}{|c|}{ Recycling } \\
\hline Own consumption & $17 \%$ & 3.06 & 5.56 & 0.000 \\
\hline Good will & $5 \%$ & 1.58 & 3.16 & 0.000 \\
\hline Self-respect & $34 \%$ & 3.06 & 11.11 & 0.000 \\
\hline Belonging & $11 \%$ & 1.79 & 6.15 & 0.000 \\
\hline Sharing & $34 \%$ & 3.06 & 11.11 & 0.000 \\
\hline \multicolumn{5}{|c|}{ Voting } \\
\hline Own consumption & $13 \%$ & 2.32 & 5.6 & 0.000 \\
\hline Good will & $2 \%$ & 1.05 & 1.9 & 0.029 \\
\hline Self-respect & $23 \%$ & 2.74 & 8.39 & 0.000 \\
\hline Belonging & $18 \%$ & 2.53 & 7.11 & 0.000 \\
\hline Sharing & $44 \%$ & 3.48 & 12.64 & 0.000 \\
\hline
\end{tabular}

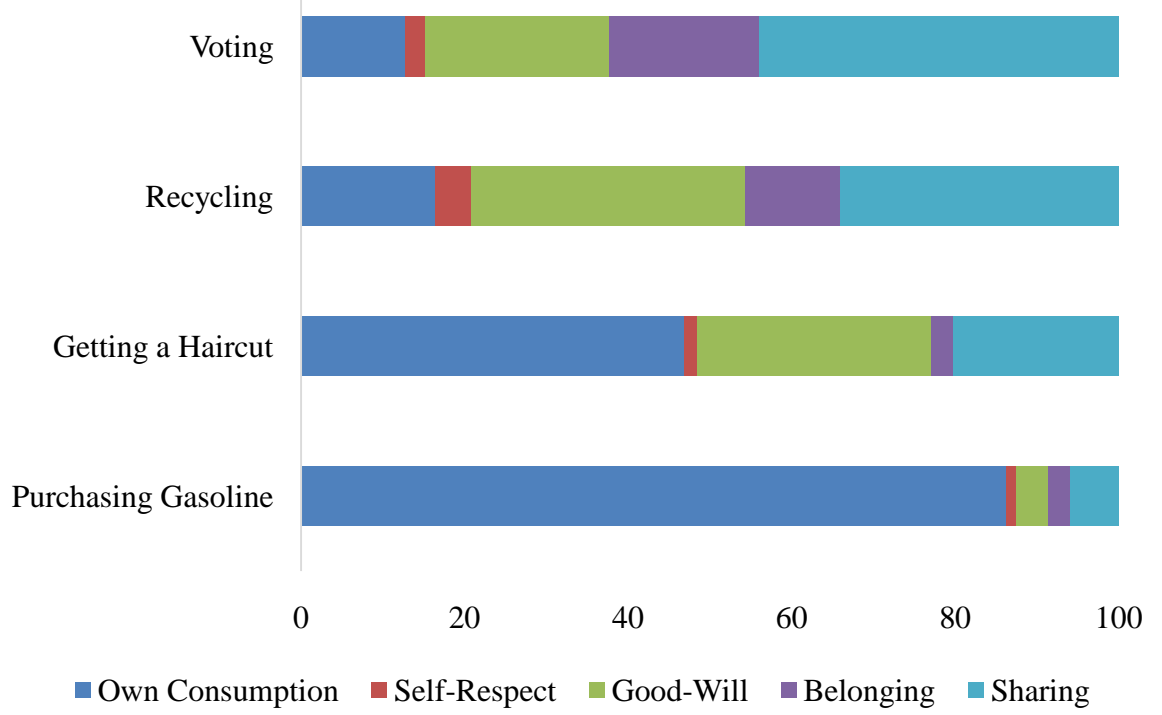

Figure 2. Average motives for each economic transaction. 
of how relationships influence the terms and level on which commodities are exchanged. Including social capital produced relational goods in commodity exchanges-alter the nature of an exchange. While before, commodities were exchanged for other commodities (including money), now commodities plus relational goods are exchange for other commodities and relational goods. Furthermore, when relational goods are not included in commodity exchange, relationships are not likely to influence the terms and level on which commodities are exchanged.

To further test our hypothesis that the relative importance of social capital motives varies with the relative amount of relational goods included in the exchange, we estimated the regression model described in Equation (1). We want to know if other control variables would influence our results, particularly relative to the importance of our social capital motives. To that end, we created a dependent variable $\left(\right.$ Social $_{i}$ ) equal to 100 minus the own-consumption motive and estimated the following equation:

$$
\text { Social }_{i}=\beta_{0}+\beta_{1} \times \text { Haircut }+\beta_{2} \times \text { Recycling }+\beta_{3} \times \text { Voting }+\beta X+\varepsilon_{i} \text {, }
$$

where Haircut is a dummy variable associated with the haircut transaction, Recycling is a dummy variable associated with the recycling transaction, Voting is a dummy variable associated with the voting transaction, $X$ is a vector of control variables, $\varepsilon_{i}$ is a normally distributed error term, and all $\beta_{i}$ are parameters to be estimated.

Table 5 reports results for regression Equation (1). The R-square suggests that the within-subjects design successfully accounts for a significant portion of the between-participant variation. Including control variables does not substantially alter our findings.

As a robustness check, we conducted an exploratory factor analysis, which confirmed that underlying factors were influencing the own-consumption motive in the relational transactions. Factor patterns from exploratory factor analysis are reported in Table 6. Overall, the two factors of commodity transaction and relational transaction explained $57.7 \%$ of the variation in the own-consumption

Table 5. Regression results.

\begin{tabular}{ccc}
\hline & Simple Model & With Controls \\
\hline Intercept & $13.822^{*}(0.755)$ & $10.035^{*}(2.810)$ \\
Purchasing a Haircut & $39.263^{*}(1.328)$ & $39.263^{*}(1.330)$ \\
Recycling & $69.803^{*}(1.184)$ & $69.803^{*}(1.186)$ \\
Voting & $73.375^{*}(1.062)$ & $73.375^{*}(1.063)$ \\
R-Square & 0.493 & 0.499 \\
\hline
\end{tabular}

Notes: Dependent variable is the sum total of social motives, equaling 100 minus the own consumption motive, which has a sample mean of 59.426 and a standard deviation of 41.995. An asterisk represents statistical significance at the $\alpha=0.05$ level. Values in parentheses are standard errors and are clustered at the participant level. Number of participants is equal to 1045 and the number of reported motives was $1045 \times 4$ $=4180$. Controls include race, household income, education, age, and gender with which the participant was involved. 
Table 6. Factor patterns of the own consumption motives for each relational transaction.

\begin{tabular}{ccc}
\hline & Commodity Transaction & Relational Transaction \\
\hline Buying Gasoline & 0.788 & -0.056 \\
Getting a Haircut & 0.740 & 0.302 \\
Recycling & -0.119 & 0.662 \\
Voting & -0.132 & 0.761 \\
\hline
\end{tabular}

Notes: The first latent factor (Commodity Transaction) explained $29.9 \%$ of the variation in the own-consumption data, and the second latent factor (Relational Transaction) explained $27.8 \%$ of the variation in the own-consumption data.

values. The factor patterns suggest that the selected products successfully fit the experimental design and support the notion that some economic transactions rely more on social relationships than do others. That is, plotting the factor patterns for each of the four items, the quadrant location of each of them suggests that we studied one pure commodity (purchasing gasoline), one monetary transaction with relational aspects (purchasing a haircut), and two nonmonetary transactions with relational aspects (voting and recycling).

\section{Conclusion}

The evidence from this study suggests that neoclassical economic models can describe well commodity exchanges between strangers. However, the selfish or own consumption motive may not explain exchanges that include significant relational goods. Furthermore, our evidence supports the hypothesis that as the relative importance of relational goods in exchanges increases, the relative importance of social capital motives increases as well. The connections between exchanges of relational goods and social capital motives provide an explanation of how relationships influence the terms and level of exchange.

While this study helps explain the important role of relationships in exchanges, some limitations should be considered when interpreting our results. First, our empirical findings rely on self-reported motives that may be inconsistent with a person's actual motives. Future research might utilize a non-hypothetical experiment where researchers confront participants with actual commodity and relational good choices. Furthermore, there may be alternative explanations of our findings. By utilizing the within-subjects design, we sought to control for this concern, although the potential bias remains.

Finally, we believe our study has important policy implications. By focusing on the importance of relationships on the terms and level of exchange, behavioral economists and economic sociologists have been better able to identify how to incentivize positive social outcomes (Bénabou \& Tirole, 2006; Bögenhold, 2013). For example, Thaler and Sunstein (2009) demonstrate how intangible (relational goods) have been used to increase tax receipts and voluntary savings.

Another important policy implication of this study follows from the evidence that an agent's well-being depends on the consumption of both commodities 
and relational goods. These results suggest that there may exist opportunities to maintain or even increase our collective well-being by emphasizing the production of relational goods and reducing the emphasis on the production of commodities-and in the process reduce the environmental strains on our natural resources that commodity production and consumption requires.

By emphasizing the importance of relational goods in important economic transactions, policymakers might be able to better predict outcomes and encourage prosocial behavior. Already, efforts have been employed to use what we have called here, relational goods, to "nudge" behavior toward prosocial outcomes. Our findings also suggest opportunities to evaluate the role of social capital and relational goods in other social and economic exchanges.

\section{Conflicts of Interest}

The authors declare no conflicts of interest regarding the publication of this paper.

\section{References}

Abrams, S., Iversen, T., \& Soskice, D. (2010). Informal Social Networks and Rational Voting. British Journal of Political Science, 41, 229-257. https://doi.org/10.1017/S0007123410000499

Ariely, D. (2008). Predictably Irrational: The Hidden Forces That Shape Our Decisions. New York: Harper Collins Publishers.

Barile, L., Cullis, J., \& Jones, P. (2015). Will One Size Fit All? Incentives Designed to Nurture Prosocial Behaviour. Journal of Behavioral and Experimental Economics, 57, 9-16. https://doi.org/10.1016/j.socec.2015.04.004

Basker, E., Foster, L., \& Klimek, S. D. (2017). Customer-Employee Substitution: Evidence from Gasoline Stations. Journal of Economics and Management Strategy, 26, 876-896. https://doi.org/10.1111/jems.12215

Battaglini, M., Díaz, C., \& Patacchini, E. (2017). Self-Control and Peer Groups: An Empirical Analysis. Journal of Economic Behavior \& Organization, 134, 240-254. https://doi.org/10.1016/j.jebo.2016.12.018

Becchetti, L. A., Pelloni, \& Rossetti, F. (2008). Relational Goods, Sociability, and Happiness. Kyklos, 61, 343-363. https://doi.org/10.1111/j.1467-6435.2008.00405.x

Becchetti, L., Trovato, G., \& Londono Bedoya, D. A. (2011). Income, Relational Goods and Happiness. Applied Economics, 43, 273-290. https://doi.org/10.1080/00036840802570439

Becker, J. U., \& Clement, M. (2006). Dynamics of Illegal Participation in Peer-to-Peer Networks-Why Do People Illegally Share Media Files? Journal of Media Economics, 19, 7-32. https://doi.org/10.1207/s15327736me1901 2

Bénabou, R., \& Tirole, J. (2006). Incentives and Prosocial Behavior. American Economic Review, 96, 1652-1678. https://doi.org/10.1257/aer.96.5.1652

Berinsky, A. J., Huber, G. A., \& Lenz, G. S. (2012). Evaluating Online Labor Markets for Experimental Research: Amazon.com's Mechanical Turk. Political Analysis, 20, 351-368. https://doi.org/10.1093/pan/mpr057

Biggart, N. W., \& Castanias, R. P. (2001). Collateralized Social Relations: The Social in Economic Calculation. American Journal of Economics and Sociology, 60, 471-500. 
https://doi.org/10.1111/1536-7150.00071

Bögenhold, D. (2013). Social Network Analysis and the Sociology of Economics: Filling a Blind Spot with the Idea of Social Embeddedness. American Journal of Economics and Sociology, 72, 293-318. https://doi.org/10.1111/ajes.12005

Brennan, G., \& Lomasky, L. (1997). Democracy and Decision: The Pure Theory of Electoral Preference. Cambridge: Cambridge University Press.

Bruni, L., \& Stanca, L. (2008). Watching Alone: Relational Goods, Television and Happiness. Journal of Economic Behavior and Organization, 65, 506-528. https://doi.org/10.1016/j.jebo.2005.12.005

Bruni, L., \& Sugden, R. (2000). Moral Canals: Trust and Social Capital in the Work of Hume, Smith and Genovesi. Economics \& Philosophy, 16, 21-45. https://doi.org/10.1017/S0266267100000122

Caplan, B. (2011). The Myth of the Rational Voter: Why Democracies Choose Bad Policies. Princeton, NJ: Princeton University Press. https://doi.org/10.2307/j.ctvcm4gf2

de Mello, L., \& Tiongson, E. R. (2009). What Is the Value of (My and My Family's) Good Health? Kyklos, 62, 594-610. https://doi.org/10.1111/j.1467-6435.2009.00453.x

DellaVigna, S., List, J. A., Malmendier, U., \& Rao, G. (2016). Voting to Tell Others. Review of Economic Studies, 84, 143-181. https://doi.org/10.1093/restud/rdw056

Dupuis, M., Endicott-Popovsky, B., \& Crossler, R. (2013). An Analysis of the Use of Amazon's Mechanical Turk for Survey Research in the Cloud. In Proceedings of the International Conference on Cloud Security Management: ICCSM 2013 (pp. 10-18). Seattle, Washington, USA: University of Washington.

Etzioni, A. (1991). Socio-Economics: A Budding Challenge. In Socio-Economics: Toward a New Synthesis (p. 3). Armonk, NY: M.E. Sharpe. https://doi.org/10.1016/S1053-5357(05)80006-X

Feddersen, T., \& Sandroni, A. (2006). A Theory of Participation in Elections. American Economic Review, 96, 1271-1282. https://doi.org/10.1257/aer.96.4.1271

Frank, R. H. (2008). The Status of Moral Emotions in Consequentialist Moral Reasoning. In P. J. Zak (Ed.), Moral Markets: The Critical Role of Values in the Economy (pp. 42-59). Princeton, NJ: Princeton University Press.

https://doi.org/10.1515/9781400837366.42

Frey, B. S. (2007). Awards as Compensation. European Management Review, 4, 6-14. https://doi.org/10.1057/palgrave.emr.1500068

Granovetter, M. (1985). Economic Action and Social Structure: The Problem of Embeddedness. The American Journal of Sociology, 91, 487. https://doi.org/10.1086/228311

Greene, J. (2014). Moral Tribes: Emotion, Reason, and the Gap between Us and Them. New York: Penguin.

Gui, B., \& Sugden, R. (2005). Economics and Social Interaction. Cambridge: Cambridge University Press. https://doi.org/10.1017/CBO9780511522154

Haidt, J. (2012). The Righteous Mind: Why Good People Are Divided by Politics and Religion. New York: Vintage Books.

Hauser, D. J., \& Schwarz, N. (2016). Attentive Turkers: MTurk Participants Perform Better on Online Attention Checks than Do Subject Pool Participants. Behavior Research Methods, 48, 400-407. https://doi.org/10.3758/s13428-015-0578-Z

Hitlin, P. (2016). Research in the Crowdsourcing Age: A Case Study. Washington DC: Pew Research Center.

Hoff, K., \& Stiglitz, J. E. (2016). Striving for Balance in Economics: Towards a Theory of 
the Social Determination of Behavior. Journal of Economic Behavior and Organization, 126, 25-57. https://doi.org/10.1016/j.jebo.2016.01.005

Joshi, S. V., Robison, L. J., Jin, S., Winder, R., \& Shupp, R. S. (2015). Selfishness and Social Capital Motives and Recycling Behavior. In American Economic Association/Allied Social Science Association Meetings (pp. 2-3).

Kahneman, D., \& Deaton, A. (2010). High Income Improves Evaluation of Life But Not Emotional Well-Being. Proceedings of the National Academy of Sciences, 107, 16489-16493. https://doi.org/10.1073/pnas.1011492107

Kim, H. H. (2009). Market Uncertainty and Socially Embedded Reputation. American Journal of Economics and Sociology, 68, 679-701. https://doi.org/10.1111/j.1536-7150.2009.00644.x

Kocher, M. G., Martinsson, P., Myrseth, K. O. R., \& Wollbrant, C. E. (2017). Strong, Bold, and Kind: Self-Control and Cooperation in Social Dilemmas. Experimental Economics, 20, 44-69. https://doi.org/10.1007/s10683-015-9475-7

Kosonen, T. (2015). More and Cheaper Haircuts after VAT Cut? On the Efficiency and Incidence of Service Sector Consumption Taxes. Journal of Public Economics, 131, 87-100. https://doi.org/10.1016/j.jpubeco.2015.09.006

Lopes, H. (2008). From Self-Interest Motives to Justice Motives: The Challenges of Some Experimental Results. American Journal of Economics and Sociology, 67, 287-313. https://doi.org/10.1111/j.1536-7150.2008.00571.x

Malone, T., \& Lusk, J. L. (2016). Putting the Chicken before the Egg Price: An Ex Post Analysis of California's Battery Cage Ban. Journal of Agricultural and Resource Economics, 41, 518-532.

Manski, C. F. (2000). Economic Analysis of Social Interactions. Journal of Economic Perspectives, 14, 115-136. https://doi.org/10.1257/jep.14.3.115

Maslow, A. H. (1943). A Theory of Human Motivation. Psychological Review, 50, 370-396. https://doi.org/10.1037/h0054346

Mason, W., \& Suri, S. (2012). Conducting Behavioral Research on Amazon's Mechanical Turk. Behavior Research Methods, 44, 1-23. https://doi.org/10.3758/s13428-011-0124-6

Nolan, S. A., \& Heinzen, T. (2015). Step-By-Step Solutions: T-Tests: Paired/Dependent and Independent. West Lafayette, IN: Purdue University.

Perry, G. M., \& Robison, L. J. (2001). Evaluating the Influence of Personal Relationships on Land Sale Prices: A Case Study in Oregon. Land Economics, 77, 385-398. https://doi.org/10.2307/3147132

Polanyi, K. (1944). The Great Transformation: The Political and Economic Origins of Our Time. New York: Farrar \& Rinehart Publ.

Rand, A. (1964). The Virtue of Selfishness. New York: Penguin.

Rasciute, S., Downward, P., \& Greene, W. H. (2017). Do Relational Goods Raise Well-Being? An Econometric Analysis. Eastern Economic Journal, 43, 563-579. https://doi.org/10.1057/eej.2015.46

Robison, L. J., \& Flora, J. L. (2003). The Social Capital Paradigm: Bridging across Disciplines. American Journal of Agricultural Economics, 85, 1187-1193. https://doi.org/10.1111/j.0092-5853.2003.00528.x

Robison, L. J., \& Oliver, J. R. (2019). Rationalizing Predictably Irrational Choices: The Social Capital Synthesis. The Annals of Regional Science, 1-21. https://doi.org/10.1007/s00168-019-00945-8

Robison, L. J., \& Ritchie, B. K. (2010). Relationship Economics: The Social Capital Para- 
digm and Its Application to Business, Politics, and Other Transactions. London: Grower Publishers.

Robison, L. J., \& Schmid, A. A. (1991). Interpersonal Relationships and Preferences: Evidence and Implications. In R. Frantz, \& H. Singh (Eds.), Handbook of Behavioral Economics (Vol. 2, pp. 347-358). Greenwich, CT: JAI Press.

Robison, L. J., Schmid, A. A., \& Siles, M. E. (2002). Is Social Capital Really Capital? Review of Social Economy, 60, 1-21. https://doi.org/10.1080/00346760110127074

Robison, L. J., Shupp, R. S., Jin, S., Siles, M. E., \& Ferrarini, T. H. (2012). The Relative Importance of Selfishness and Social Capital Motives. Journal of Socio-Economics, 41, 118-127. https://doi.org/10.1016/j.socec.2011.10.008

Siles, M., Robison, L. J., Johnson, B., Lynne, G. D., \& Beveridge, M. D. (2000). Farmland Exchanges: Selection of Trading Partners, Terms of Trade, and Social Capital. Journal of the American Society of Farm Managers and Rural Appraisers, 63, 127-140.

Thaler, R. H., \& Sunstein, C. (2009). Nudge: Improving Decisions about Health, Wealth, and Happiness. New York: Penguin. (Updated Edition)

U.S. Census Bureau (2015). American Factfinder: Quick Facts.

Uhlaner, C. J. (1989). Relational Goods And Participation: Incorporating Sociability into a Theory of Rational Action. Public Choice, 62, 253-285.

https://doi.org/10.1007/BF02337745

Uzzi, B. (1997). Social Structure and Competition in Interfirm Networks: The Paradox of Embeddedness. Administrative Science Quarterly, 42, 35-67.

https://doi.org/10.2307/2393808 


\section{Appendix}

Each of the 1045 survey respondents reported the relative importance of their motives for each of the four transactions by allocating 100 percentage points among the five motives. While the tests reported in Table 4 suggest that each of the motives for each of the exchanges is non-zero (with the possible exception of the Good-will motive), we conducted paired t-tests using data for each participant (Nolan \& Heinzen, 2015) to see whether the differences in the own consumption motive across the four exchanges are significant. Table A1 presents the results of all combinations of paired $t$ tests.

All tests were significant at the $\alpha=0.01$ level, even between the two purely social capital dependent transactions (recycling and voting). These results suggest that the own consumption motive, while not dominant in relational good choices is still a choice factor and can vary among different relational transactions. As indicated in Table A1 there was considerable variation in the mean differences of the pairs. For example, gas purchases and voting had a 74.4 percentage-point difference in the allocation of points for the own consumption motive. These results support the view that selfish motives dominate gas purchases but not relational exchange activities like voting and recycling. Furthermore, as the goods tended to reflect more relational transaction properties, such as voting and recycling, the difference between the average own-consumption motive and other motives increased.

Table A1. Paired T tests of mean differences in own-consumption motive ratings.

\begin{tabular}{cccccc}
\hline & Mean diff. & S.E. & t-statistic & \multicolumn{2}{c}{$p$-value } \\
\hline Gas-Hair & 40.25 & 1.36 & 29.57 & 0.000 & $* * *$ \\
Gas-Recycle & 70.38 & 1.21 & 58.40 & 0.000 & $* * *$ \\
Gas-Vote & 74.40 & 1.05 & 70.92 & 0.000 & $* * *$ \\
Hair-Recycle & 30.14 & 1.58 & 19.02 & 0.000 & $* * *$ \\
Hair-Vote & 34.15 & 1.42 & 23.99 & 0.000 & $* * *$ \\
Recycle-Vote & 4.01 & 1.11 & 3.62 & 0.000 & $* * *$ \\
\hline
\end{tabular}

